\title{
ON THE STATUS OF DISCOURSE MARKERS*
}

\author{
CSILLA ILONA DÉR \\ Department of Hungarian Linguistics \\ Károli Gáspár University of the Reformed Church \\ Reviczky u. 4/C \\ H-1088 Budapest \\ Hungary \\ csillader@gmail.com
}

\begin{abstract}
Research on discourse markers has run into fundamental difficulties recently. First, that group of linguistic items appears to withstand approaches trying to account for them in terms of formal properties, even though the set of discourse markers includes a subset, that of discourse particles, that is somewhat easier to characterise in formal terms. Secondly, a function-based description of discourse markers has its own problems, too: it is not easy to find the common denominator of all the diverse roles that the relevant literature attributes to them. A substantial part of the latter difficulty has its roots in the fact that, to date, no adequate and full-fledged classification has been proposed with respect to linguistic units having a pragmatic role, including discourse markers.

No increase in the amount of empirical research does, in itself, present a way out of that situation: successful continuation of such research and general theoretical advancement both require that certain fundamental issues be clarified first. The purpose of this paper, accordingly, is to reveal certain difficulties in referring to and characterizing discourse markers (via a review of the relevant literature), claiming that some of their allegedly canonical properties are oversimplified or downright wrong. Also, an effort is made to highlight crucial functional aspects of the delimitation of the group of discourse markers and to discuss the status of multi-word discourse markers, too.
\end{abstract}

Keywords: discourse marker, pragmatic marker, discourse particle, functional description, multi-word discourse marker

* I wish to acknowledge the generous help I received in writing this paper from members of the Functional linguistics workshop of Eötvös Loránd University, Budapest, and from the reviewers of this paper. I also wish to thank Mária Ladányi for the numerous pieces of advice and encouragement I received from her. 


\section{Introduction}

The investigation of discourse markers is an intriguing task for the linguist: on the one hand, this group of items seems to defy all attempts to account for its members in terms of parts of speech or individual formal properties (rather than in terms of function); on the other hand, as we will see, their functional description is not unproblematic, either: it keeps revealing new difficulties as it goes on. The purpose of this paper is to review the major theoretical problems related to discourse markers as they appear in the current literature, ${ }^{1}$ including difficulties in referring to them and in listing their definitive features, and to explore crucial functional aspects of delimiting the group of pragmatically loaded linguistic units. The latter attempt is needed because an increase in the amount of empirical research devoted to discourse markers does not, in itself, show us a way out of the chaotic situation we encounter at present: successful continuation of such research and theoretical advancement both require that certain fundamental issues be clarified first. In addition, I will briefly consider the status of multi-word discourse markers, a topic that is present in the international literature but is not sufficiently in the foreground there, in my view.

The structure of this paper is as follows: in section $\mathbf{2}$, I investigate the terms used to denote discourse markers. I compare them with each other and propose a way of eliminating terminological discrepancies. In section 3, I review (allegedly) relevant semantic-pragmatic and formal-syntactic properties of discourse markers, focusing on the problems with these features and confronting them with the results of the most recent research. At the end of this section, I provide a summary of which features, on this analysis, turned out to be defensible, and which less important. In section 4, I scrutinize problems of multi-word discourse markers with the aim of elucidating why they are seen, by many scholars of pragmatics, less important than one-word markers, and how certain types of these constructions can be delimited from each other. Finally, I make a proposal on how to describe discourse marking elements with the same function but with different forms. In the closing section (5), I explore functions assigned to discourse markers with special attention to the problem of the reconciliation of these functions. I claim that some reduction of these

${ }^{1}$ In all cases where various Hungarian authors have contributed to the raising and elaboration of the problems at hand, I will briefly refer to their work. 
functions is necessary in order to gain a clearer starting point in working with discourse markers.

In the course of my investigation I will refer to theories of functionalist linguistics, mainly to coherence theory, but my objective is to find a common ground in the description of discourse markers.

\section{Terminological issues}

A number of terms are in use in referring to discourse markers, ${ }^{2}$ a fact that has been claimed to be a symptom of the uncertainty of their status (cf. Furkó 2005, 17). ${ }^{3}$ It should be added that the terminological diversity often reflects theoretical distinctions, either between formal and functional approaches or within the functional approach. It is rather difficult to sort out the variants; for instance, in the case of part-of-speech labels (like conjunction, connective, particle, or the Hungarian term módositószó 'modifying word'), it is impossible to tell whether the researcher using such terms thinks that it is only members of that particular class that belong to the group of discourse markers (and takes discourse marking to be just another function of the given part of speech) or indeed other items belong there, too. Some terms appear to be too broad or too narrow to use for discourse markers even if that category is based on a very wide range of functions. Heterogeneity (of both the source items and the specified functions of discourse markers) makes the picture even more blurred. In sum, the terms are often rather misleading: sometimes the term suggests a category that is narrower than what turns out to be referred to by it (a case in point is Csüry's (2005) term konnektor 'connective'), and sometimes the opposite situation obtains (as in the case of discourse particle).

In what follows, the four terms that occur most often in the literature will be considered in detail. ${ }^{4}$ The term discourse marker (abbreviated

2 As a matter of interest, note that I have counted up to 42 different English terms and up to 29 different Hungarian terms (cf. Brinton 1996, 29; Schourup 1999).

${ }^{3}$ We could also say that the fact that the 'naming process' has not yet come to an end reflects the prevalence of theoretical uncertainties.

4 To illustrate preferences and orders of magnitude, here are the results of a Google search of 6 November 2008: discourse marker(s): 95,200 hits, discourse particle(s): 23,100 hits, pragmatic marker(s): 14,120 hits, pragmatic particle(s): 4,800 hits. Note that I have only searched for English terms but the hit counts are not of 
as DM) - whose Hungarian loan translation is diskurzusjelölő (and the less frequent társalgásjelölö 'conversation marker') - is currently the most widespread in the linguistics literature written in English. Other terms that often crop up are pragmatic marker (PM), discourse particle (DP), and pragmatic particle $(\mathrm{PP})$-indeed, these four are the most typical options since the latter half of the 1990s.

The term discourse particle was popular mainly up to the mideighties (Schourup 1999, 229), and it is still widely used by researchers of languages other than English (like German, French, etc., cf. Müller 2005, 2-3). But there are also exceptions like Fischer and others who use $D P$ and $D M$ in two distinct senses (Fischer 2006, 4). A quick Google search (see footnote 4 ) confirms that $D P$ is used rather frequently even today. It maintains its ground despite the fact that its use has been severely criticised (e.g., by Schourup 1999, 229) for involving the word particle. The main objection is that particle is a widely used syntactic term-a fact that restricts the range of items it can be applied to. For instance, discourse particle is inappropriate to refer to multi-word discourse markers; and discourse markers tend to be syntactically heterogeneous anyway. The name of a group of items delimited on a formal (syntactic) basis to refer to discourse markers that are organised in terms of function is an unfortunate choice to begin with (although it is understandable why those preferring a formal approach are keen on using it). Another problem with the term discourse particle is that 'particle' is used by many as a kind of waste-basket category for function words that do not fit anywhere else (cf. Haspelmath 2001, 16539). Furkó $(2005,20)$ says that DP is also problematic in that it is used for scalar and modal particles on the one hand, and for linguistic items that belong to the range involved in the German tradition of particle research (e.g., aber 'but', allerdings 'indeed', auch 'also', denn 'thus, so', doch 'but, still', freilich 'of course, admittedly') on the other.

Despite the foregoing considerations, many researchers use the term $D P$; their reason may be, for instance, that of Fischer $(2006,4)$ who applies it to short and uninflected words loosely integrated in the structure of the sentence, deliberately distinguishing them from larger units of a similar (pragmatic) function, like idioms. She also thinks that DPs contrast with clitics, full words, and bound morphemes, and include

course restricted to papers on English or to research conducted by native speakers of English. 
items like okay, hmm, oh, well..$^{5}$ For Fischer, $D M$ is a purely functional term - as opposed to $D P$ that she takes to refer to a subclass of DMs delimited by the above formal criteria (idem.). On the other hand, she does not take multi-word items to belong to the larger category of DMs, either: "Using the term discourse particle furthermore distinguishes discourse particles/markers from larger entities, such as phrasal idioms, that fulfil similar functions" (Fischer 2006, 4). However, she does not give any reason for why idioms could not be DMs, except for the fact that she takes the purely functional approach to DMs to be debatable (ibid., 5). As she points out, a purely functional classification does not permit size-based distinctions or those in terms of the degree of idiomaticity, or indeed those based on loss of semantic transparency (idem.). During the elaboration of her debatable point of view she nevertheless clearly states that despite arguments supporting a purely functional categorisation, research on discourse markers primarily focuses on particles and conjunctions (idem.). In addition, another point of her paper reveals that she takes DPs to be lexicalised units whereas DMs include non-lexicalised items as well (ibid., 7).

The above view of "DPs as a subset of DMs" can be debated on the basis of Furkó $(2005,20)$ who says that one of the most conspicuous features of DMs is their syntactic independence, a feature that is often not exhibited by modal particles (although it is an open question what 'independence' really means here: that they cannot form a constituent with other expressions or rather that they can occupy certain syntactic positions and not others, cf. Gyuris 2008). The most important problem with the term discourse particle, in my view, is that-although it is a lot narrower, hence apparently more circumscribed, category than that of discourse markers - its extension varies author by author. It is often meant to refer to a small set of items, whose members are not taken to be discourse markers by everyone; and in addition, the term particle covers, over and above pragmatic-modal particles, also propositional (enhancing) particles. Yet the latter by no means belong functionally to discourse markers. On other occasions, the notion is taken to be very broad (by, e.g., Levinson 1983, 163; cf. Furkó 2005, 20; cf. the categorisation of even, like, or all right as DPs). The problem with pragmatic particle is roughly the same as that with discourse particle.

${ }^{5}$ Cf. Gyuris (2008), who analyses the following Hungarian items as DPs: csak 'after all; nevertheless', ugye 'don't you think' [question tag], vajon 'whether; I wonder', talán 'perhaps', legalább 'at least'. 
With respect to the relationship between pragmatic marker and discourse marker, four different views are in existence:

I. The two terms are synonymous ${ }^{6}$ - this is claimed by e.g., Brinton (1996) or Andersen (2001) (cf. Müller 2005, 3). Brinton has opted for PM rather than $D M$ because, although she thinks that both are rather broad terms, the former is better at covering the totality of the functions of the items at hand (Brinton 1996, 29-30).

II. DM is a superordinate category: Redeker (1990), for instance, says that pragmatic markers constitute a subtype of discourse markers: semantic discourse markers signal ideational structure, whereas pragmatic discourse markers (i.e., pragmatic markers) signal pragmatic structure.

III. PM is a superordinate category that includes DMs: the most important representative of this view is Fraser, who says that PMs are characterised by the following features: they constitute part of a discourse segment but not part of the propositional content of the message; they encode aspects of the speaker's immediate communicative intention (Fraser 1997, 115-6). They are typically (but not exclusively) free morphemes occurring in an initial position (within the discourse segment), introducing a special message and classifiable on the basis of their semantic-pragmatic (rather than syntactic) function. It is also important that Fraser includes among PMs, in addition to lexically occurring items, also other instantiations of modality (e.g., indicative mood in the case of The cat is sick), as well as stress and intonation (idem., and op.cit., 125). Pragmatic markers have four types, according to Fraser (1996; 1997; the examples are also taken from him):

(a) basic PMs signal the type of message (illocutionary force) that the speaker intends to convey by the utterance, e.g., I promise that $I$ will be on time. Along with performative expressions, the ways of expressing modality also belong here. Fraser says that all sentences must include at least one basic PM (whereas the occurrence of the other three types is optional).

${ }^{6}$ This is made possible by the fact that PMs are claimed to have a number of different functions that largely overlap with those of DMs. For instance, Brinton (1996, 30-1) lists the following PM functions found in the relevant literature: the expression of the relation or relevance of an utterance to the preceding utterance or to the context; structural function; response signal function; means to achieve conversational continuity; interactive function. 
(b) commentary PMs signal messages that are distinct from the basic message and are commenting on it (subtypes include e.g., qualifying, attitudinal, etc. PMs), e.g., We got lost almost immediately. Fortunately, a police officer happened by. They often take the form of pragmatic idioms, e.g., I'm not an expert, but shouldn't we be there by now?

(c) parallel PMs also signal messages that are distinct from the basic message. They have two types: honorifics, e.g., Sir, Your honour, and markers that make conversation work smoothly: Well, we could do it either of two ways. ${ }^{7}$

(d) DMs signal the relationship between the discourse segment including them and the previous segment, e.g., Donna left late. However, she arrived on time.

IV. Furkó (2005, 23-5), working in a relevance-theoretical framework, subscribes to a fourth approach: he thinks that the dichotomy of PM vs.

DM can and must be eliminated, for two reasons. First, DMs do not indicate relationships between discourse segments but between contextual assumptions or premises that are based either on co-text or on context, and given that such assumptions continually and mutually affect each other, the items signalling their relationships cannot be taken either exclusively pragmatic (context-dependent) or exclusively discourse (co-text-dependent) markers. Secondly, these items exhibit multifunctionality as a basic trait (for instance, they can simultaneously signal discourse organisation and speaker's attitude, as illustrated by Furkó using the following example: A: What are you going to do now? B: Well, I'm moving out. In this example, well is a DM as it indicates a message linked to the previous segment and also a PM as it can signal that B takes A's face into account and is reluctant to give a straight answer). That is, the PM:DM opposition is untenable because individual tokens may cut across the distinction between the two categories (Furkó 2005, 23, 26; cf. Fraser 1999, 942).

In Hungarian research on discourse markers, two of the above four terms "compete" with one another: diskurzusjelölo" 'discourse marker' (or its variant társalgásjelölo" 'conversation marker') and diskurzuspartikula 'discourse particle'. Because of the problems concerning the latter, discussed above, I think it would be most advisable to use the former term,

${ }^{7}$ We must admit that it is difficult for us to see why these two are taken to form a single category. 
especially the version diskurzusjelölö, for several reasons. Társalgás 'conversation' is a narrower notion than diskurzus 'discourse', hence sticking to the latter we would not constrain the range of genres in which these items are expected to occur. Using diskurzusjelölő does not merely indicate an unambiguous link with the international literature but it also can conveniently accommodate diverse parts of speech and larger-than-word units as well. As we saw above, the hierarchical relationship between DM and PM can depend on theoretical considerations; but I think diskurzusjelölő can be construed as narrower than pragmatikai jelölö ${ }^{8}$ if we take it to be a name for some (but not all!) units serving a pragmatic function. ${ }^{9}$

\section{Characteristic features of discourse markers}

In the past decade, several papers summarised the properties of discourse markers (e.g., Fraser 1999, 943-6; Schourup 1999, 230-4; Müller 2005, 5-8; Furkó 2005, 55-71), The discussion below will focus only on those features of discourse markers that are relevant and problematic in some sense.

\subsection{Semantic-pragmatic features}

Semantic-pragmatic features that define an item as a discourse marker are the following:

Non-propositionality (= non-truth-conditionality): it is often mentioned in the literature that discourse markers have a procedural (rather than conceptual) meaning, ${ }^{10}$ and that they do not alter the truth conditions of the proposition expressed in the given utterance. In several

${ }^{8}$ Pragmatics can be considered either as a comprehensive discipline which contains discourse analysis, conversation analysis etc., or as a separate but related field also addressing language use (cf. Németh T.-Bibok 2003, 5-6).

${ }^{9}$ It would be a good idea, by the way, to assign separate names to other pragmatic markers, too (just like Fraser 1996 does), to avoid the problem that it is only a single subtype of pragmatic markers, viz. discourse markers, that has a name of its own.

${ }^{10}$ According to researchers working in a relevance-theoretical framework, conceptual and procedural meaning are to be distinguished sharply (e.g., WilsonSperber 1993; Blakemore 1992), because they reflect a cognitive opposition: the sharp distinction between representation and computation (Hedley 2007, 36).

Acta Linguistica Hungarica 57, 2010 
places, only one of the above statements is given, whereas in some other places, they are not clearly distinguished. For instance, Schourup (1999, 245) asks the question of whether or not they are the same statement. Wilson and Sperber (1993) claim they are not, given that there are cases in which an expression is simultaneously conceptual and non-truthconditional or procedural and truth-conditional. For instance, frankly as a discourse marker is non-truth-conditional and conceptual in the following case: (Speaking quite) frankly, I don't think you're right. The meaning of frankly would be conceptual here because it can be combined with other lexical items to produce a semantically complex unit. In Schourup's view, if this were true, using truth-conditionality as a criterion of DM status would lead to forcing very different items into the same class. Therefore, it would have to be decided case by case whether a given item has or does not have conceptual meaning (idem.). In his view, if this differentiation were tenable, two very different classes of discourse markers would exist, and - citing Blakemore (1996) - that would put an end to the explanatory force and theoretical value of the term discourse marker. All I would like to add here is that the problem seems to be restricted to items exhibiting non-truth-conditional but conceptual meanings, referred to above. However, DMs that have a conceptual meaning do not fatally divide the category in my view and do not represent insuperable theoretical problems, either (for details, see the next paragraph).

Procedural meaning (= non-compositionality): Undoubtedly, one of the most typical traits of descriptions of discourse markers is the statement that these linguistic units have a procedural meaning. Blakemore (2002) links conceptual vs. procedural meaning with compositionality: if the meaning of an item is compositional, it must also be conceptual. She uses synonymy as a criterion, too ${ }^{11}$ that is, if a discourse marker is synonymous with its non-discourse-marking counterpart, its meaning is conceptual; examples include that is and in other words, whereas a counterexample - i.e., a non-synonymous pair of homophones - is well (Blakemore 1987; 2002). This latter criterion is not unproblematic in my view, namely synonymy and non-synonymy are not separated from each other by a clear-cut dividing line. The problem of conceptual meaning is especially severe with respect to multi-word discourse markers. Items like Hungarian hogy úgy mondjam 'so to say' are peculiar in that they

${ }^{11}$ It is not quite clear why Blakemore refers to the relationship between the discourse marker and non-discourse-marker functions of an item as "synonymy", even if the two meanings are not really far from one another. 
do not necessarily go back to a non-discourse-marking source item (cf. Dömötör 2008a: "it first entered the language 'fully armed' as a discourse marker"). And as far as conceptual meaning itself is concerned, it can be misleading as a criterion in that even if the meaning of a discourse marker is (or seems to be) conceptual, its function may clearly be pragmatic and text-level, e.g.,

- Non-discourse-marking function: Hogyan lehet mondani más szóval, hogy szerény és makacs? 'How do you say 'modest' and 'stubborn' in other words? ${ }^{12}$

- Discourse marking function: Szerintem a modern angol költészet, költészetünknek egy igen érdekes része, müfordításokból áll. Más szóval, a müforditás érvényes müfaj. 'I think modern English poetry, a very interesting part of our poetry, consists of translations. In other words, poetic translations constitute a valid genre.' (Hungarian National Corpus)

To complicate matters further, discourse markers that go back to a source item with a different part-of-speech affiliation (e.g., mellesleg 'incidentally', tényleg 'actually' - the respective source items are no more used in present-day Hungarian) have a history in which, necessarily, there must have been a period in which the given item was ambiguous, that is, both its old and new readings were possible (compare this with general regularities of grammaticalisation, cf. Heine et al. 1991, 46-7). Hence, the procedural meaning of DMs must have been preceded, at some point in the past, by a conceptual meaning (the later meaning can always be derived from the earlier one, that is, the procedural from the conceptual), and the two must have been separated by a conceptual-procedural period (cf. Furkó 2005, 48). What kind of meaning a given DM has essentially depends on how far it has got in this grammaticalisation process. It is an open question, then, whether the conceptual/procedural distinction is relevant at all in the case of discourse markers - in my view, because of the above considerations, it is not. This conclusion is also supported by Fraser (2006) where the author points out that the conceptual/procedural opposition cannot be upheld either for discourse markers or indeed for pronouns since they have a conceptual meaning alongside the procedural one; illocutionary adverbs, on the other hand, have a procedural meaning alongside the conceptual one.

\footnotetext{
12 http://www.gyakorikerdesek.hu/kozoktatas-tanfolyamok_hazifeladat-kerdesek60212-hogy-lehet-mondani-mas-szoval-hogy-szereny-es-makacs
} 
Multifunctionality: this can apply to DMs in two different respects: first, discourse markers as a group may have several meanings (e.g., the following subtypes may be distinguished: turn taking signals, hesitation signals, ${ }^{13}$ feedback signals); secondly, a given discourse marker may also have a number of distinct functions. For instance, Dömötör (2008b) has described a number of different discourse marking functions of úgymond 'so to say' alongside its (basic) quotation-marking role ('quoth he'), including distancing oneself from a statement; less than full identification with the words being used; signalling metaphoric use of an expression; or withdrawal of an inappropriate stylistic device. The last-mentioned function can be illustrated by the following utterance in which the speaker withdraws an overly familiar word: Ez az utolsó dolog, ami úgymond "ciki" 'This last thing that is, so to say, "sticky".' (source: www.bonusz.hu). It is especially noteworthy that a given DM may simultaneously express several functions, even totally distinct ones (cf. the example given in section $\mathbf{2}$, point IV above). This fact must be captured in the theory of the description of discourse markers.

Context-dependence: it is widely accepted that discourse markers have a context-dependent meaning (e.g., Schiffrin 1987; Fraser 1999); they are indexical (Aijmer 2002), a fact that makes them rather similar to deictics - indeed, some authors call these items discourse deictics (e.g., Levinson 2004). Furkó claims that context-dependence is a side effect of the grammaticalisation process whereby discourse markers lose their inherent, context-independent meaning and assume more subjective, textual, and interpersonal functions (Furkó 2005, 57). I could add-while I wish to keep the criterion of context-dependence - that it is difficult to delimit the individual functions (due to the "adaptive" ability of discourse markers): either too much is included or too little; or else too general functions are assigned.

Context-dependence is also the reason why, in concrete studies, the individual roles are very hard to tell apart. A case in point, again, is úgymond 'so to say' in Dömötör (2008b): one of the main functions assigned to it (drawing the hearer's attention to a semantic or stylistic peculiarity of the use of a word or phrase, with reference to shared linguistic knowledge of what would count as appropriate use) is further classified into the following subfunctions: indicating that a word is used in a non-canonical

13 The term hesitation covers here some functions of speech planning, like the intention of the speaker to gain time and/or to retain the right to speak (cf. GósyHorváth 2009). 
meaning; signalling that an expression is used metaphorically; warning that the formulation is not perfect; indicating/withdrawing an unsuccessful choice of word; or taking back an inappropriate stylistic device. In the case of the following example, Dömötör assigns the third subfunction given above - but any of the others would do just as well: Magyar tudósok úgymond külföldön próbálnak szerencsét 'Hungarian scholars try their luck abroad, so to say' (DunaTV, 6 November 2006; Dömötör notes that úgymond refers to szerencsét próbál 'try one's luck' here).

\subsection{Formal-syntactic features}

Optionality: 'Optionality' can be construed in several ways, hence it is advisable to specify whether one takes it to mean sentence-semantic facultativity or syntactic deletability of discourse markers. A third possibility also exists: with the omission of a DM, the relationship it stands for remains valid but fails to be explicitly marked. The last-mentioned case is the point concerning which the literature is the most divided: some authors say that the occurrence of a given discourse marker may well be optional, although it is always better to have it overtly since it eliminates unwanted interpretations and provides a cue to the accurate intention of the speaker (cf. Furkó 2005, 56-7); others are less permissive. As Müller $(2005,5-8)$ points out, optionality is only true in terms of grammatical wellformedness; pragmatically speaking, discourse markers can never be literally left out (they are implicitly always present). Indeed, in Müller's view, this is the one and only feature that differentiates homonymous pairs of discourse markers and non-discourse-markers. In my own view, optionality cannot really be taken to make sense pragmatically, given that in actual utterances the discourse marker is either clearly present or clearly absent, both cases being the speaker's decision, with all its consequences. Redeker (1993) says that the discourse marking relationship is eliminated whenever the discourse marker is omitted: without an overt discourse marker, the required pragmatic information is absent (cf. "where the DMs are not present, the hearer is left without a lexical clue as to the relationship intended between the two segments," Fraser 1999, 944). It can be experimentally demonstrated that whenever a discourse marker is omitted, coherent interpretation of the discourse will be deficient or downright impossible. Redeker (1993) digitally removed DMs

from the material of a two-hour televised conversation and played it to subjects: the omission of markers, especially those signalling the ends of 
discourse segments, delayed comprehension significantly. The problem is also illustrated by the following example from Schiffrin $(1987,318)$ : A: Sue dislikes all linguists. B: I like her. If we hear the two utterances in sequence, with no explicit discourse marking, we cannot tell whether the relationship is contrary ('I like her all the same' or 'I like a linguist whom Sue dislikes') or consecutive ('And that's why I like her').

Syntactic independence (weak clause association): This means that discourse markers are but loosely connected to the syntactic structure of the discourse segment concerned, or they are outside of it. It is important to note that certain DMs (some multi-word DMs) have their own syntactic structure, for example: to be more precise; frankly spoken. This feature is in connection with phonological independence: some discourse markers can behave like separate tone units (see the paragraph after the next one).

Phonological reduction: Discourse markers may also exhibit phonological reduction (some Hungarian examples: tehát 'thus'>tát; tudod 'you know'>tod; szóval 'in a word'> szal, sza; cf. Auer-Günthner 2003, 11), but not all units are affected.

Phonological independence: The idea of phonological independence often crops up in the literature (e.g., Brinton 1996, 33; Jucker-Ziv 1998, 3; Zwicky 1985, 303: "Unlike clitics, which are prosodically dependent, discourse markers and their parenthetical kin are prosodically independent. Typically, they are both accented and prosodically seperated from their surrounding context, by pauses or intonation breaks or both"); however, empirical (experimental phonetic) results are inconclusive in this respect: in one study, the English discourse marker well turned out to be an independent prosodic unit in a mere $50 \%$ of the cases (Hirschberg-Litman 1993, 516). Swedish men 'but'/'and' and sa 'so' are often preceded by pause but hardly ever followed by any (men: $90 \%$ of occurrences was preceded and $17 \%$ was followed by pause; sa occurred with a pause before it in $59 \%$ and with a pause after it in $8 \%$ of the cases, Hansson 1999). However, this study is not methodologically impeccable (small number of test items, questionable method of establishing pause durations). A similar study of Hungarian discourse markers (Dér-Markó 2007) involving 2775 tokens and 57 various types of discourse markers found that a mere $5.5 \%$ of all DMs was preceded by a pause and $8.2 \%$ was followed by one. The largest proportion of pausing $(22.5 \%)$ was observable before tehát 'that is' - but that item was quite frequently used by speakers for hesitation purposes, a possible explanation of that striking figure. The 
frequency of following pauses was under $20 \%$ for the most frequently occurring items. ${ }^{14}$ Among less frequently occurring items, the highest result was yielded by the DM ugye 'don't you think' (12 occurrences, $41.7 \%$ of which was followed by a pause); például 'for example' ( $21.4 \%$ of the 14 occurrences) and úgy 'so' (20.0\% of the 10 occurrences) were also followed by a pause in relatively many cases. Our data thus show that pausing is not really typical either before or after discourse markers in spontaneous Hungarian speech.

Initiality: It is often mentioned in the literature that DMs typically occur initially in the discourse unit (cf. Keszler's (1998) term bevezetö szók és kifejezések 'introductory words and expressions' and its French equivalents). On the other hand, Müller (2005, 5-8) claims that there is no consensus with respect to what the discourse unit concerned is: sentence, utterance, or turn. Erman found (for the pragmatic expressions she studied) that they occurred most frequently utterance/turn medially, but they even occurred sentence medially (Erman 1986, 132-3; 1987, 47; 1992, 219). Brinton (1996) also confirms that DMs often occur in sentence medial and final position. The occurrence of discourse markers in diverse positions was also confirmed by Markó and Dér (2008; 2009) with respect to the Hungarian DMs studied: only $50.9 \%$ occurred turn-initially, $18.6 \%$ turn-finally, and $11.8 \%$ as an independent turn. However, the individual DMs behaved quite diversely in this respect. For instance, $j a$ 'yeah' and $n a$ 'let me see' almost always (91.0 and $88.7 \%$ ) served as turn-initial items, de 'but' was turn-initial in $73.4 \%$, and és 'and', jó 'good', hát 'well', and nem 'no' also occurred in turn-initial position in over $50 \%$ of the cases. Typically turn-internal items were akkor 'then', egyébként 'incidentally', and especially igy 'so' and mondjuk 'let's say'.

We also looked at the positions of seven homophonous pairs (that is, seven items that occurred both as discourse markers and in other functions: igy 'so', meg 'and', most 'now', tehát 'thus', tényleg 'really', úgyhogy 'so that', and vagy 'or'). Tényleg 'really' as an adverb usually occurred clause-internally, while as a DM-introducing a new topic into the discourse - it was more typically clause-initial. Ugyhogy 'so that' as a conjunction exclusively occurred clause-initially, whereas in a DM role

${ }^{14}$ By 'most frequently occurring items', we meant discourse markers occurring 50 or more times in our material: these were the following (starting with the most frequent item and going down the frequency scale): hát 'well', igy 'so', de 'but', igen 'yes', nem 'no', és 'and', akkor 'then', ja 'yeah', tehát 'thus', mondjuk 'let's say', úgyhogy 'so that', jó 'good', egyébként 'incidentally', na 'let me see'. 
in nearly always occurred at the end of clauses. This was due to the fact that one of the speakers consistently used this item to signal that he had reached the end of what he wanted to say (and that he wished to give up the floor).

To sum up, it seems that discourse markers can occur either with a procedural or with a conceptual meaning. They either affect the truthconditions of the proposition expressed in the given utterance, or they do not. Usually they are multifunctional: the more developed a unit is in the evolutionary process of discourse markers, the more abundant is the pool of functions it covers (even simultaneously). Discourse markers are context-dependent, and their appearance is syntactically optional, but this optionality is not interpretable from a pragmatic point of view. They are only loosely attached to the syntactic structure of discourse segments that they are in connection with. These pragmatic units can be characterized by phonological reduction, although it does not necessarily take place in each case: it depends on the frequency of occurrence of the marker (more frequent items tend to undergo more phonological reduction). The features of phonological independence and segment-initial position are not valid for the whole group.

As we can see, the apprehension of discourse markers is only possible by their pragmatic function, therefore it is crucial to refine our understanding of these functions (see section $\mathbf{5}$ ). The parameters mentioned above may be more or less typical of each marker.

\section{Problems with multi-word discourse markers}

Despite the fact that much of the literature on discourse markers mentions, in addition to single-word units, also multi-word DMs (e.g., másként szólva 'in other words'; jobban mondva 'better to say'; úgy értem, hogy... 'I mean'; cf. Cuenca 2003, 1073; Csűry 2005, 80; Dömötör 2008a), and some papers even list relevant examples, there are relatively few analyses concentrating specifically on these items (notable exceptions are Siepmann (2005), and papers about the frequent you know and I mean). Part of the reason may be that multi-word units are special even within the group of DMs, heterogeneous as it is to begin with (built on source items coming from a number of different parts of speech, exhibiting diverse functions, etc.). We saw earlier on that those preferring the label discourse particle usually only include single-word discourse markers in that group and thus avoid analytic difficulties stemming from multi-word 
DMs. However, this is an arbitrary decision in the case of units that are functionally clearly related: the same function may in fact be served by single-word and multi-word forms alike ${ }^{15}$ - especially in the case of a group whose members are held together only by function.

Dirk Siepmann says multi-word discourse markers (also known as routine formulae; complex markers; second-level discourse markers - the last one is Siepmann's own term) "are medium-frequency fixed expressions or collocations composed of two or more printed words acting as a single unit" (Siepmann 2005, 52; emphasis added). ${ }^{16}$ The boldface expression is very important for a uniform treatment of members of the category DM with diverse formal properties. The above definition is theoretically quite satisfactory - but it does not always help the researcher in practical decisions since these multi-word units are often difficult to tell apart from occurrences of a sequence of two or more independent discourse markers. The latter also consist of several words whose internal relationship, however, is different: real multi-word DMs - even if they are highly idiomatic - usually have their own syntactic structure (even though some of their constituents may be ellipted and there are also exceptions, see below), whereas linked single-word DMs do not. The difficulty of distinguishing those two cases lies in the fact that both syntactic relatedness and ellipsis are difficult to ascertain in some concrete situations. In the following example, it is difficult to tell if we have to do with ellipsis or not: Akkor most azt kérdezném, hogy mi volt akkor, amikor... illetve nem, általánosságban, hogy amikor valaki végez, tehát szerez Ph.D.-fokozatot biológiából, és mondjuk itt, Magyarországon, tegyük föl, hogy Magyarországon szeretne dolgozni, akkor egyáltalán mik mik vannak elötte, milyen lehetöségeket lát 'Well then I would ask what happened

15 To illustrate: within the larger function of 'reformulation', the subfunction of exemplification can be expressed, along with single-word items like például 'for instance' or mondjuk 'let's say', by a number of multi-word DMs, too: hogy egy példával éljek 'to give an example here'; ezek közé tartozik, hogy... 'one of the relevant cases is. . '; vegyük azt a példát, hogy. . . 'let us take the example that...', etc. Multi-word DMs usually have single-word equivalents; exceptions to that generalisation, in Siepmann's view, are DMs having a complex function such as his excluders, expressing that some portion of the preceding discourse segment would deserve more detailed elaboration but this is not possible for some reason, e.g., Space limitations preclude...; We have space enough to mention only a few...; This is not the place (cf.op.cit., 93-4).

${ }^{16}$ Siepmann specifically studied written scholarly texts, hence the word printed in his definition. 
when... or rather not $[=$ ? or rather, I would not ask that but $]$ in general, when somebody finishes his studies, that is, gets a Ph.D. in biology, and say here in Hungary, let us assume, it is in Hungary that he would like to get a job, then what at all what is ahead of him, what possibilities does he see. ${ }^{17}$ In the excerpt below, it is not easy to decide whether we have a sequence of two single-word DMs or a single multi-word DM: próbáljuk valamihez kötni, tehát mondjuk van saját csoportja, vagy vagy saját témán saját pénze 'let us pin this down, that is, let's say he has a team of his own or or money of his own on a topic of his own'. The former assumption is supported by the fact that, by omitting either tehát or mondjuk, we do not get an ungrammatical sentence, while such partial omission cannot be done with real multi-word DMs (except in cases where this results in another DM, either a single-word or a multi-word one, as in pontosabban $\sim$ pontosabban szólva $\sim$ pontosabban szólva azt mondhatnánk, hogy.. . 'more exactly $\sim$ more exactly speaking $\sim$ we could say more exactly speaking that...'). In the example involving tehát mondjuk, the item mondjuk 'let's say' exemplifies "the point of transition" between single-word and multi-word DMs: if some arguments are overtly present, e.g., mondjuk azt, hogy... 'let us say that...', it is a multi-word discourse marker; if they are not, it is formally a single-word DM.

Adjacent single-word DMs can have the same function, or different functions. In the following example, two different subtypes of reformulation ${ }^{18}$ occur side by side: mittomén (< mit tudom én) 'I dunno' serves illustration, while szóval 'well' serves elaboration: olyan dolgok esnek meg az [...]-ban, amit egy cégnél nem tolerálnának, mittomén... szóval az embernek úgy el lehet évekig ott úgy piszmogni 'such things happen in [...] that would not be tolerated in a firm, I dunno, well, one can carry on pottering about there for years'. Single- and multi-word DMs can also be combined: tehát tulajdonképpen az első pillanattól kezdve világos volt, hogy én haza szeretnék jönni. . és gyakorlatilag április óta, jobban mondva hát év eleje óta, de április óta hivatalosan újra itthon... 'so

17 The source of linguistic examples in this section, unless otherwise indicated, is a six-participant recorded conversation (interview). The specifics are: length of recording: 2 hours 6 minutes; 3 male and 3 female subjects; all university graduates and aged between 34 and 40 years; the topic of conversation is biologists' careers.

${ }^{18}$ Following Del Saz Rubio-Fraser $(2003,5-9)$ we can list the following subfunctions: expansion (including elaboration, definition, identification, illustration); compression; modification (narrowing down, correcting); and reassessment. 
in fact it was clear from the very first moment that I wanted to come home... and practically since April, or better to say well from the beginning of the year, but officially since April, [I was] at home again'. In this case, it is unclear whether the single-word DM hát that follows the multi-word DM jobban mondva has the same function or a different function. In Németh T.'s view, hát 'well' has a reformulating function: "in the speech of the same speaker, it is a tool for self-correction, or entering into explanations" (Németh T. 1998, 327, see also 329). That is, we could speak of the same function in the case of jobban mondva hát, in which case hát emphasises the preceding discourse marker.

The idea might occur that perhaps ability to form collocations could also be used as a criterion for telling apart several single-word DMs and multi-word DMs; this, however, would not work since the former can also enter into collocations, e.g., de egyébként 'but incidentally', és íg 'and so', most igy 'now so', tehát igy 'thus so' (cf. Dér-Markó 2007). A further possibility would be the separability of adjacent members; the following example shows single-word DMs of the same function being separated: $\boldsymbol{s}$ Andrisba meg megbizok 'and Andy, I trust him' (where both $s$ and meg mean 'and', cf. Markó-Dér 2008). The problem with this criterion is that a number of multi-word discourse markers exist that are "separated" (or, contain gaps) to begin with, and one or several of their parts are to be "filled in", for instance: by ... we mean; hasonlítsuk össze ...-t ...-vel 'let us compare ... with ...'; egyrészrőll..., másrészröl... 'on the one hand ..., on the other hand ...'; az egy dolog, hogy..., az pedig egy másik, hogy... 'it is one thing to ... and another thing to ...', etc. (cf. Siepmann 2005, 82ff).

Another open question is how to deal, from a theoretical point of view, with multi-word DMs that have formally more or less distinct versions with the same function (e.g., például, hogy egy példát is mondjak, egy példával élve, hogy egy példával éljünk - all: 'for instance'), that is, whether we should take each version to be a distinct DM or else we should allow for the possibility of variation (and if we do, how far are we prepared to go, cf. Siepmann 2005, 45-51).

Summarizing this section, I can say that we have no fully reliable cues for distinguishing strings of single-word DMs from multi-word DMs, but if we use several criteria in tandem, we can determine which unit belongs to which category (the criterion of having syntactic structure usually works, except for the egyfelöl-másfelól 'on the one hand-on the other hand' type). However, we also have to reckon with the existence 
of transitional cases. Another way could be to analyse the diachronic evolution of these forms: it can possibly tell us which markers stand in an ancestor-descendent relation to each other. Alternatively, we could decide to assign the forms to discourse functions, by which move the question of the number of words would be skipped as not so relevant.

\section{The functions of discourse markers}

The functions of DMs are often practically equated with the categories occurring in taxonomies (this is also shown by the fact that such categories are usually not grouped into larger functions). This, of course, is not unreasonable; but now I am looking for the major functions of discourse markers.

It appears that the number of functions proposed in the literature varies widely. The broadest approaches assign one large function to all discourse markers, such as 'the indication of discourse structure' (Schiffrin 1987) or 'metacommunicative function' (Furkó 2005), and then go into details in functional classification. If we summarised discourse marking functions listed by the various authors, probably metacommunicative function would be the "lowest common multiple" - but for empirical investigations, it is obviously too broad a category.

In most cases, however, we see examples where two or three sets of functions are defined, typically along the following lines (cf. Müller 2005, 8-9; Andersen 1998, 147): textual functions (primarily discussed by authors working in a coherence-theoretical framework); interactional functions (mostly described by representatives of relevance theory); and attitudinal functions (also with relevance theorists). Hence, which function occurs/dominates with which author also depends on theoretical affiliation.

Simone Müller speaks of two functions of discourse markers (where the last two of the above triplet are amalgamated into a single function): textual functions are not directly addressed to the listener but either refer to lexical expressions, e.g., in terms of how exact or appropriate they are, or concentrate on the propositional content conveyed by discourse units of various length (ranging from a single word to utterances describing a full scenario), or rather the relationships of those propositional contents. For instance, they may indicate transition from one scene to another, or shifting from the major train of thought to examples and back, or indeed they may indicate the beginning of a quotation (cf. Dömötör 
2008a,b). Interactional functions, on the other hand, are served by DMs concentrating on the relationship between speaker and listener, indicating speech acts, replies, opinions, or evaluations, or expressing that the speaker is turning directly to the listener (e.g., by drawing her attention to a single word, with DMs such as like). Illustrating the foregoing on some uses of the discourse marker you know (cf. Müller 2005, 147ff; the examples are also from her): ${ }^{19}$

An example of the textual function is self-correction:

(1) it was rocky... rocky so they were kind of roll... you know rocking back and forth

and another example is quotation:

(2) there is a big door that says marriage licenses, so um Charlie asks the girl you know shall we get married and this sort of thing

An instance of the interactional function is reference to shared knowledge or its use: in what follows, the speaker draws the listener's attention to a piece of information that was mentioned earlier during the conversation:

(3) A: while... this guy is getting beaten up, there's the bird ${ }^{20}$

B: yeah

A: you know that he meets on the ship

B: yeah and and yeah

In Müller's view, reference to some conclusion is also interactional: in the following excerpt, the speaker asks for a conclusion, suggesting by her intonation that the listener is able to draw that conclusion:

19 Müller analysed the Giessen-Long Beach Chaplin Corpus (GLBCC); the examples in the text come from her book (suitably abridged and with special transcription symbols omitted). GLBCC contains conversations in which pairs of students discuss a Chaplin film seen earlier, on the basis of questions provided by the experimenters (e.g., Did you like the film? Which was the funniest part? What was the acting of major/minor characters like?) The experimenters decided for this kind of fixed-topic approach in order to be able to record and compare phenomena like how the speaker introduces the various characters, known or not yet known by the listener (for details, see Müller 2005, 31-6).

${ }^{20}$ Bird refers to a woman on the ship who Chaplin falls in love with and gives money to. 
(4) A: and he goes to pay the bill... and the waiter... bends the coin it's no good you know

B: oh

A: so then he doesn't know what he's gonna do

Other researchers organise the above discourse marking functions into a unified system: according to Siepmann $(2005,83)$, discourse markers may reflect the following coherence relations:

- Relations establishing a link between discourse units that describe 'real-world' states and processes: ideational, semantic, content, external, subject-matter or propositional relations. For instance: cause and effect, sequence, contrast.

- Relations establishing a link between the illocutionary force of one discourse unit and the locutionary meaning of another: interpersonal, pragmatic, internal, rhetorical, procedural, presentational, metadiscursive relations, e.g., criticizing, justifying, concluding.

Metadiscourse, in turn, can again be of two types (Hyland 1998, 442-3):

- textual metadiscourse: "refers to devices which allow the recovery of the writer's intention by explicitly establishing preferred interpretations of propositional meanings";

- interpersonal metadiscourse: "alert[s] readers to the author's perspective towards both the propositional information and the readers themselves, thus contributing to a writer-reader relationship and anticipating the subjective negatability of statements".

The latter may apparently include discourse markers expressing the author's comments/opinions as well as units that present the speaker's/ writer's opinion on the proposition at hand. Therefore, we can speak of a narrower and a broader attitudinal function (where the former includes proposition-related DMs only while the latter also includes units expressing other aspects of the speaker's perspective). A third version is also conceivable in which only speech situation related discourse markers are involved, and proposition-related attitudinal markers are missing. However, if attitude marking is taken in the narrow sense, connecting cannot occur; but in my view, connecting is a fundamental feature of discourse markers that also serves for delimiting them from other (pragmatic) markers. Another argument against associating an attitudinal function with discourse markers may be that, in certain authors' view, 
attitude markers are not connected to the speech situation like other discourse markers but rather to the situation that is being talked about (cf. Németh T. 1996).

In sum, I think that discourse markers fundamentally carry textual functions, and attitude markers must be separated as a distinct group of pragmatic markers. As we have seen, the identification of functions may be theory-dependent. Following from aforementioned conclusions, I find the approach of coherence theory (e.g., Schiffrin 1987; Redeker 1990; Lenk 1998) the most adequate for the description of discourse markers.

On the basis of the foregoing considerations, we can ask whether the range of proposed discourse marking functions is not too broad to make a unified treatment possible. Given that we have to do with a class organised on a functional basis, the appropriate delimitation of functions is of utmost significance; but it is also important because it might help resolve the terminological chaos in the literature, referred to above. However, this will not take place until agreement is reached on basic functional considerations that should underlie the classification of linguistic items having a pragmatic function.

As we have seen, I would only assign textual functions to discourse markers within the group of pragmatic markers, and relate attitude marking clearly to a different class within the latter (in Fraser 1997, they are called "commentary pragmatic markers", see section $\mathbf{2}$ ). Of course, it all depends on how we define attitude marking (e.g., whether we include face work in these functions or we do not). If we mean attitude marking very broadly, then it will be typical of many discourse markers. This might also be a viable alternative, but the separation of these functions with respect to text coherence and comprehension has more advantages for the description.

I do not agree with claims to the effect that it is sufficient to carry on and expand empirical research in the hope that it will lead us out of the terminological maze we encounter today; rather, I think that functional descriptions, taxonomies, and further research should be built on a sound theoretical basis that is accepted by everybody. In my view, Fraser' ${ }^{21}$

21 Many of my papers mentioned above (Dér 2005; 2008; also Dér-Markó 2007; forthcoming; Markó-Dér 2008; 2009) are based on Fraser's works (1996; 1997; 1999; 2006). 
typology and definition referred to earlier - suitably reformulated, if necessary - can be used successfully as a basis for further empirical research as well as for novel theoretical descriptions.

\section{References}

Aijmer, Karin 2002. English discourse particles. Evidence from corpora. John Benjamins, Amsterdam \& Philadelphia.

Andersen, Gisle 1998. The pragmatic marker like from a relevance-theoretic perspective. In: Jucker-Ziv (1998, 147-70).

Andersen, Gisle 2001. Pragmatic markers and sociolinguistic variation: A relevancetheoretic approach to the language of adolescents. John Benjamins, Amsterdam \& Philadelphia.

Auer, Peter - Susanne Günthner 2003. Die Entstehung von Diskursmarkern im Deutschen - ein Fall von Grammatikalisierung? In: InLiSt - Interaction and Linguistic Structures 38. (http://kops.ub.uni-konstanz.de/volltexte/2003/1145/pdf/Inlist38.pdf)

Blakemore, Diane 1987. Semantic constraints on relevance. Blackwell, Cambridge MA \& Oxford.

Blakemore, Diane 1992. Understanding utterances. An introduction to pragmatics. Blackwell, Cambridge MA \& Oxford.

Blakemore, Diane 1996. Are apposition markers discourse markers? In: Journal of Linguistics $32: 325-47$.

Blakemore, Diane 2002. Relevance and linguistic meaning. The semantics and pragmatics of discourse markers. Cambridge University Press, Cambridge.

Brinton, Laurel J. 1996. Pragmatic markers in English. Grammaticalization and discourse functions. Mouton de Gruyter, Berlin \& New York.

Csüry, István 2005. Kis könyv a konnektorokról [A small book on connectives] (Officina Textologica 13). Kossuth Egyetemi Kiadó, Debrecen.

Cuenca, Maria-Josep 2003. Two ways to reformulate: A contrastive analysis of reformulation markers. In: Journal of Pragmatics 35 : 1069-93.

Del Saz Rubio, Milagros - Bruce Fraser 2003. Reformulation in English. Manuscript. (http://people.bu.edu/bfraser/Reformulation\%20Marker\%20Papers/deSaz\%20 \&\%20Fraser\%20-\%202003\%20-\%20RF\%20in\%20English.doc)

Dér, Csilla Ilona 2005. Diskurzusszerveződés és grammatikalizáció - néhány magyar diskurzusjelölő kialakulásáról [Discourse organization and grammaticalization on the evolution of some Hungarian discourse markers]. In: Nyelvtudományi Közlemények $102: 247-264$.

Dér, Csilla Ilona 2008. Grammatikalizáció [Grammaticalization] (Nyelvtudományi Értekezések 158). Akadémiai Kiadó, Budapest. 
Dér, Csilla Ilona - Alexandra Markó 2007. A magyar diskurzusjelölők szupraszegmentális jelöltsége [Suprasegmental markedness of Hungarian discourse markers]. In: Tamás Gecső - Csilla Sárdi (eds): Nyelvelmélet - nyelvhasználat [Linguistic theory and language use] (Segédkönyvek a nyelvészet tanulmányozásához 74), 61-7. Kodolányi János Főiskola \& Tinta Könyvkiadó, Székesfehérvár \& Budapest.

Dér, Csilla Ilona - Alexandra Markó forthcoming. A pilot study of Hungarian discourse markers. In: Language and Speech 53(2).

Dömötör, Adrienne 2008a. A hogy úgy mondjam diskurzusjelölő [The discourse marker hogy úgy mondjam 'so to say']. In: Magyar Nyelv 104:427-42.

Dömötör, Adrienne 2008b. Az úgy mond-tól az úgymond-ig. Egy diskurzusjelölő elem története az ómagyar kortól napjainkig [From úgy mond 'quoth he' to úgymond 'so to speak'. The story of a discourse marker from Old Hungarian to the present]. In: Magyar Nyelvőr 132:37-52.

Erman, Britt 1986. Some pragmatic expressions in English conversation. In: Gunnel Tottie-Ingegerd Bäcklund (eds): English in speech and writing. A symposium, 131-47. Almqvist \& Wiksell, Stockholm.

Erman, Britt 1987. Pragmatic expressions in English. Almqvist \& Wiksell, Stockholm.

Erman, Britt 1992. Female and male usage of pragmatic expressions in same-sex and mixed-sex interaction. In: Language Variation and Change $4: 217-34$.

Fischer, Kerstin 2006. Towards an understanding of the spectrum of approaches to discourse particles: Introduction to the volume. In: Kerstin Fischer (ed.): Approaches to discourse particles, 1-20. Elsevier, Oxford.

Fraser, Bruce 1996. Pragmatic markers. In: Pragmatics $6: 167-90$.

Fraser, Bruce 1997. Commentary pragmatic markers in English. In: Estudios Ingleses de la Universidad Complutense $5: 115-27$.

Fraser, Bruce 1999. What are discourse markers? In: Journal of Pragmatics 31:931-52.

Fraser, Bruce 2006. On the conceptual-procedural distinction. In: Style 40. (http://findarticles.com/p/articles/mi_m2342/is_1-2_40/ai_n17113874)

Furkó, Bálint Péter 2005. The pragmatic marker-discourse marker dichotomy reconsidered - The case of well and of course. Doctoral dissertation, Debreceni Egyetem Bölcsészettudományi Kar, Debrecen.

Gósy, Mária - Viktória Horváth 2009. Hogyan tükrözi a kiejtés a nyelvi funkció változását? [How does pronunciation reflect the change of language function?]. In: Borbála Keszler - Szilárd Tátrai (eds): Diskurzus a grammatikában - grammatika a diskurzusban [Discourse in grammar - grammar in discourse], 37-45. Tinta Könyvkiadó, Budapest.

Gyuris, Beáta 2008. A diskurzus-partikulák formális vizsgálata felé [Towards a formal investigation of discourse particles]. In: Ferenc Kiefer (ed.): Strukturális magyar nyelvtan 4. A szótár szerkezete [A structural grammar of Hungarian 4. The structure of the lexicon], 639-82. Akadémiai Kiadó, Budapest.

Hansson, Petra 1999. Discourse markers in dialogue. In: Jens Allwood (ed.): Proceedings of FONETIK 99. The Swedish Phonetics Conference, June 2-4 1999 (Gothenburg Papers in Theoretical Linguistics 81), 65-8. Göteborg University Department of Linguistics, Gothenburg. 
Haspelmath, Martin 2001. Word classes/parts of speech. In: Paul B. Baltes-Neil J. Smelser (eds): International encyclopedia of the social and behavioral sciences, 16538-45. Pergamon, Amsterdam.

Hedley, Paul 2007. Anaphora, relevance, and the conceptual/procedural distinction. Doctoral dissertation, University of Oxford.

Heine, Bernd - Ulrike Claudi - Friederike Hünnemeyer 1991. From cognition to grammar. Evidence from African languages. In: Elizabeth Closs Traugott-Bernd Heine (eds): Approaches to grammaticalization. Vol II: Focus on types of grammatical markers (Typological Studies in Language 19/1, 2), 149-89. John Benjamins, Amsterdam \& Philadelphia.

Hirschberg, Julia-Diane Litman 1993. Empirical studies on disambiguation of cue phrases. In: Computational Linguistics 19:501-3.

Hyland, Ken 1998. Persuasion and context: The pragmatics of academic metadiscourse. In: Journal of Pragmatic $30: 437-55$.

Jucker, Andreas H.- Yael Ziv (eds) 1998. Discourse markers: Description and theory. John Benjamins, Amsterdam \& Philadelphia.

Keszler, Borbála 1998. Bevezető szók és kifejezések [Introductory words and expressions]. In: András Zoltán (ed.): Nyelv, stílus, irodalom. Köszöntő könyv Péter Mihály 70. születésnapjára [Language, style, and literature. A Festschrift for Mihály Péter on his 70th birthday], 296-8. ELTE BTK Keleti Szláv és Balti Filológia Tanszék, Budapest.

Lenk, Uta 1998. Marking discourse coherence: Functions of discourse markers in spoken English. Gunter Narr Verlag, Tübingen.

Levinson, Stephen C. 1983. Pragmatics. Cambridge University Press, Cambridge.

Levinson, Stephen C. 2004. Deixis. In: Laurence R. Horn-Gregory Ward (eds): The handbook of pragmatics, 97-121. Blackwell, Oxford \& Malden MA.

Markó, Alexandra - Csilla Ilona Dér 2008. Magyar diskurzusjelölők korpuszalapú vizsgálata [A corpus-based study of Hungarian discourse markers]. In: András Bereczki - Márta Csepregi - László Klima (eds): Urálisztikai Tanulmányok 18. Ünnepi írások Havas Ferenc tiszteletére [Papers in Uralistics 18. A Festschrift for Ferenc Havas], 535-56. ELTE BTK Finnugor Tanszék-Numi-Tórem Finnugor Alapítvány, Budapest.

Markó, Alexandra - Csilla Ilona Dér 2009. How to distinguish? A corpus-based study of Hungarian discourse markers. In: Zsolt Lengyel-Judit Navracsics (eds): Tanulmányok a mentális lexikonról/Studies on the mental lexicon. Nyelvelsajátítás beszédprodukció - beszédpercepció/Language acquisition - speech production speech perception, 393-408. Tinta Könyvkiadó.

Müller, Simone 2005. Discourse markers in native and non-native English discourse. John Benjamins, Amsterdam \& Philadelphia.

Németh T., Enikő 1996. On the role of pragmatic connectives in Hungarian spoken discourses. ERIC Document Reproduction Service No. ED 379 937. Washington DC.

Németh T., Enikő 1998. A hát, így, tehát, mert kötőszók pragmatikai funkciójának vizsgálata [The pragmatic function of the conjunctions hát 'well', igy 'so', tehát 'thus', mert 'because']. In: Magyar Nyelv $94: 324-31$. 
Németh T., Enikő-Károly Bibok 2003. Szerkesztői bevezetés [Editorial introduction]. In: Általános Nyelvészeti Tanulmányok 20:5-9.

Redeker, Gisela 1990. Ideational and pragmatic markers of discourse structure. In: Journal of Pragmatics $14: 367-381$.

Redeker, Gisela 1993. Discourse markers as attentional cues to discourse structure. Poster presented at the 'Psycholinguistic Poster Session', LSA Annual Meeting, Los Angeles, January 1993.

Schiffrin, Deborah 1987. Discourse markers. Cambridge University Press, Cambridge.

Schourup, Lawrence 1999. Discourse markers. Tutorial overview. In: Lingua 107 : 227-65.

Siepmann, Dirk 2005. Discourse markers across languages. A contrastive study of second-level discourse markers in native and non-native text with implications for general and pedagogic lexicography. Routledge, Abingdon \& New York.

Wilson, Deirdre - Dan Sperber 1993. Linguistic form and relevance. In: Lingua 90 : 1-25. (www.phon.ucl.ac.uk/home/deirdre/papers/Linguistic\%20form\%20and\%20relevance.doc)

Zwicky, Arnold M. 1985. Clitics and particles. In: Language 61:283-305. 